\title{
Reactional and differentiated pyroxenite xenoliths from alkaline basalts of the Vitim volcanic field (East Siberia): their role in metasomatism and position in mantle magmatic system
}

\author{
Litasov K.D., Litasov Yu.D.
}

United Institute of Geology. Geophysics and Mineralogy SB RAS, Novosibirsk. 630090, Russia

Introduction. Three major groups of mantle-derived xenoliths in Miocene picrobasalts of the Vitim volcanic field were described (cf. Ashchepkov et al., 1994; Ashchepkov, Andre, 1998): (1) Group I (green) peridotites and pyroxenites, (2) Group II (black) pyroxenites, (3) pyroxene megacrysts and related pyroxenites. There are also reactional pyroxenites, metasomatic veins and differentiated pyroxenites, of which the mineral compositions are intermediate between three above groups, so called «transitional» pyroxenites (Fig. 1). We obtained ion microprobe data on minerals from pyroxenite xenoliths to consider differentiation paths of mantle melts and to highlight evolutionary features of mantle magmatic system

Results. We determined the types of «transitional» pyroxenites and related rocks as following: (1a) Amphibole-phlogopite and phlogopite-clinopyroxene veins, often crosscutting garnet lherzolites. Amph- and phl-bearing Vitim xenoliths are described in (Litasov Yu. et al., this volume). The origin of these rocks is in relation with reactional pyroxenites. (1b) Reactional ilmenite- and phlogopite-bearing garnet orthopyroxenites are found in contact with garnet lherzolite, as it is evidenced from composite xenoliths. Like the hydrous veinlets, they strongly change major element
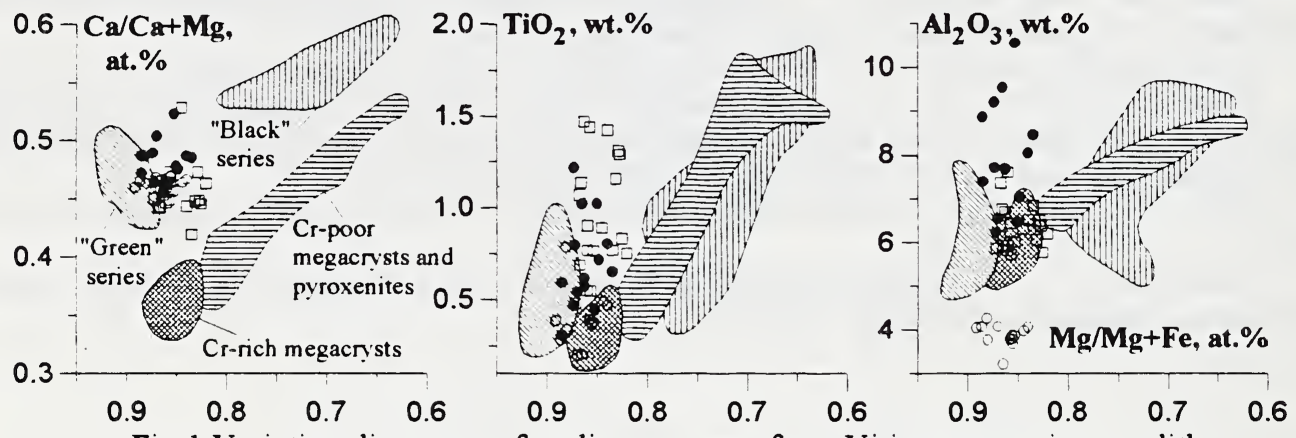

Fig.1.Variation diagramms for clinopyroxene from Vitim pyroxenite xenoliths squares - amph-phl- and px-phl-veins and reactional orthopyroxenites. solid circlesHi-Al garnet clinopyroxenites. open circles - Low-Al depleted websterites.

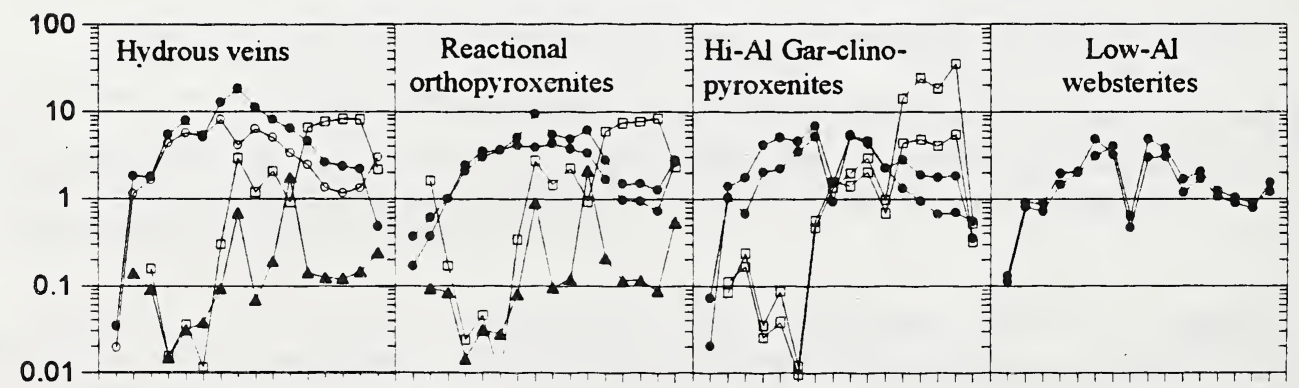

$\mathrm{BaNb}$ CeNdSm Ti Er Yb Ba NbCeNdSm Ti Er Yb Ba Nb CeNdSm Ti Er Yb Ba Nb Ce NdSm Ti Er Yb

Th La Sr Zr Eu Dy Y Cr Th La Sr Zr Eu Dy Y Cr Th La Sr Zr Eu Dy Y Cr Th La Sr Zr Eu Dy Y Cr

Fig.2. Trace element data for minerals from "transitional" pyroxenite xenoliths of the

Vitim volcanic field.

solid circles - pyroxenite clinopyroxenes, open circle - peridotite clinopyroxene, squares - garnet, triangles orthopyroxene. Trace element abundances are normalized to primitive mantle [McDonough. Sun. 1995]. 
composition of peridotite minerals towards enrichment in basaltic components. Garnet or spinel, if present, tend to breakdown with formation of hydrous Al-rich phases. Clinopyroxene mode decreases towards the contacts. Trace element partitioning in minerals (Fig.2) is similar for (1a) and (1b). They have positive $\mathrm{Zr}$ and $\mathrm{Ti}$ anomalies in relic clinopyroxene, strong HFSE-enrichment in orthopyroxene, and $\mathrm{Zr}$-peak in garnet. (2) Gray-colored high-Al garnet clinopyroxenites are of cumulative origin according to their texture and mineral chemistry. Minerals are slightly enriched in $\mathrm{Ti}$ and depleted in $\mathrm{Cr}$, although not that strong as the megacrysts are. HFSE-depletion of
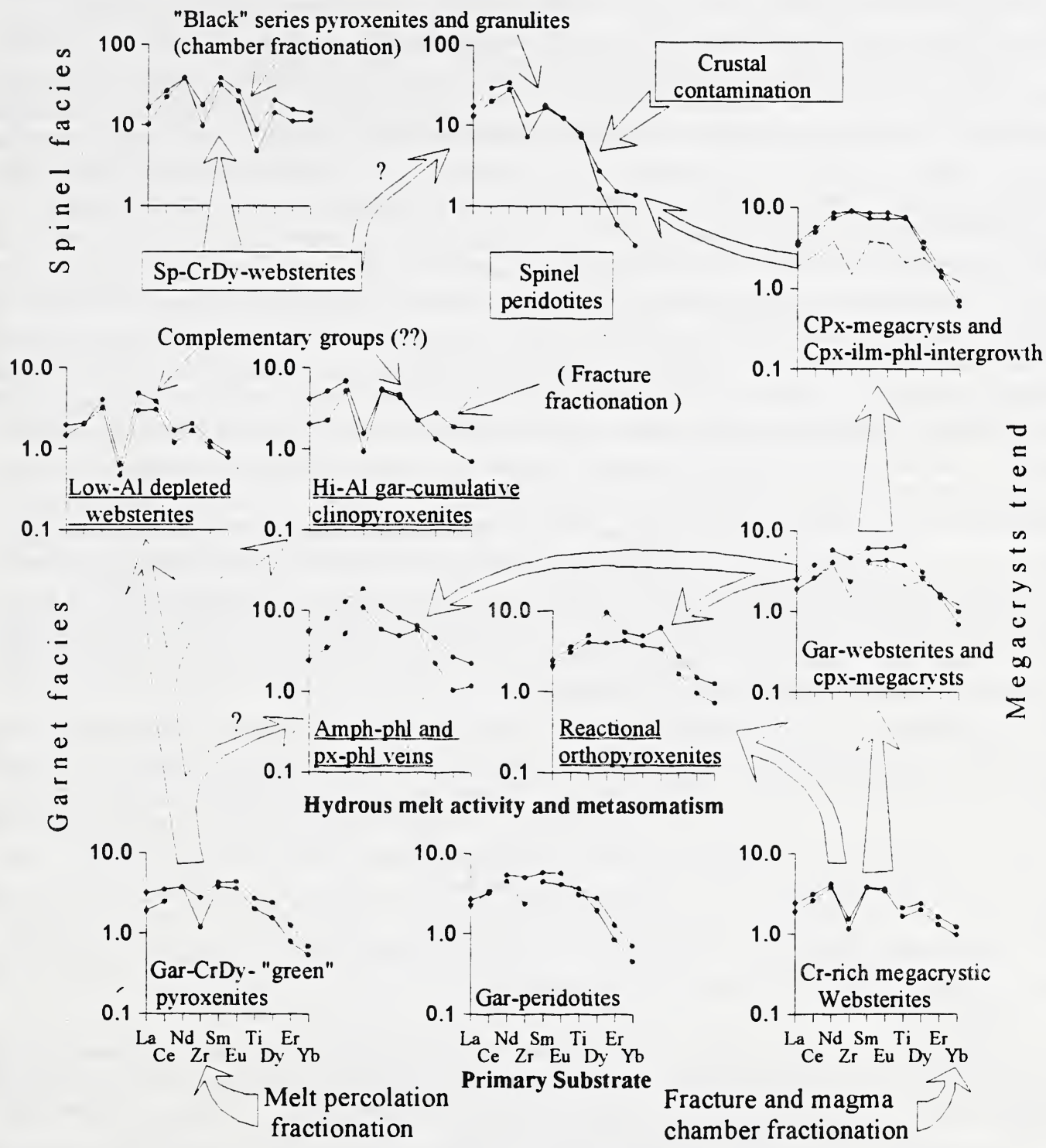

\section{Plume (OIB-like) source}

Fig.3. Clinopyroxene trace element partitioning and model of mantle magmatism beneath the Vitim volcanic field.

Data by ion microprobe. Data for megacrysts mainly from [Ashchepkov, Andre, 1998]. Trace element abundances normalized to primitive mantle [McDonough, Sun, 1995]. 
clinopyroxene indicates its relationship with Group I pyroxenites. (3) Low-Al websterite veins were found, contacting with garnet and spinel peridotites. These rocks have equigranular texture. They are composed of depleted pyroxenes. $\mathrm{Ga}$ is strongly kelyphitized. Rare spinel has high $\mathrm{Cr} \#$. One sample contains interstitial graphite. Clinopyroxene is slightly depleted in LREE, enriched in $\mathrm{Cr}$, and has strong negative HFSE-anomaly (Fig.2).

P-T-estimations. Among the Vitim xenoliths, reactional rocks - except high-Al pyroxenites mostly correspond to garnet facies under conditions of 21-25 kbar and relatively low temperatures 950-1050 ${ }^{\circ} \mathrm{C}$ (T- Brey, Kohler, 1990 and P- Nickel, Green, 1985)). They form a geotherm less hot than one for both «green» and megacrystic garnet websterites (Ashchepkov et al., 1994).

Model. Mantle magmatism and volcanism in the Vitim area is defined by plume activity with OIB-type isotopic and trace element characteristics. Two major groups of Vitim pyroxenites - Group I websterites and megacrysts with related pyroxenites (Fig.3) - correspond to major types of mantle melt movement, of which the end members are percolation fractonation and fracture fractionation (Melting and melt..., 1993, and others). The first deals with fractionation of melt as pervasive porous media flow with continuous element exchange (including compartible) with peridotite matrix. The second is determined by fractionation in hydraulic fractures dominated by pure Raleyh fractionation (for the Vitim megacrysts, basic postulates of the last process as a pulsatory polybaric fractionation of basaltic melt are described in (Ashchepkov, Andre, 1998)). Most active modifying agent is HFSErich volatile-saturated melt, of which an influence is recorded as a formation of hydrous phases composing patches, veinlets and veins in garnet peridotites and reactional ilmenite-bearing orthopyroxenites along the contacts with wall. Percolating melts responsible for the formation of Group I pyroxenites can be again segregated in places to form melt portions enable for fracture fractionation and formation of cumulates such as gray-colored high-Al pyroxenites. The formation of depleted low-Al pyroxenites may be explained by (1) percolation of reduced fluid extracting basaltic components and recrystallizing primary phases of Group I pyroxenites, (2) percolation of reduced melt through depleted peridotite and formation of depleted Group I pyroxenite veins. The first explanation concedes a complementary origin of both high-Al and low-Al rocks. In the final stage, derivates of Group I and megacryst series melts in spinel facies level and magmatic bodies of Group II pyroxenites near the Moho boundary are formed.

Conclusions. Thus, we assume following mechanisms of melt behavior responsible for the origin of «transitional» pyroxenites and hydrous veins in the Vitim xenoliths: (1) Reaction between basaltic melt and wall peridotite. (2) Fractionation of percolating melt. (3) Fluid percolation through heterogeneous matrix. The position of rare HFSE-rich ilmenite orthopyroxenites allows to clear up the origin of resembling metasomatic rocks in kimberlites, where they are more common. These metasomatic rocks may characterize a plume activity in the continental rift settings and may be an important source for HFSE-enrichment of basalts extracted from HFSE-depleted peridotite source.

Acknowledgments. Author thanks A.V.Sobolev for providing ion microprope analyses. The work is supported by RFBR grant № 97-05-65309.

\section{References}

Ashchepkov, 1.V., Litasov, Yu.D.. and Dobretsov, N.L., 1994 Pyroxenites and composite garnet peridotite xenoliths from picrite-basalt, Vitim plateau (Trans Baikal): Implication for termobarometry and mantle reconstruction // In «Kimberlite, related rocks and mantle xenoliths», Proc. 5th Int. Kimb. Conf., v.1/A, Rio de Janeiro. Brasil, p. $455-466$.

Ashchepkov, I.V., and Andre. L., 1998, Mantle-seated differentiation of alkaline mantle melts beneath the Vitim plateau (Siberia, Russia): the role of garnet: Journal of Petrology, in press.

McDonough, W.F., and Sun, S.S., 1995, The composition of the Earth: Chemical Geology, v.120, p.223-253.

Melting and melt movement in the Earth. 1993: Cox, K.G., McKenzie, D., White, R.S., eds., Oxford Sci. Publ., 222p 